\author{
J.M. ALIMOV ${ }^{1}$, N.S. KARIMOVA
}

${ }^{1}$ The Republican Specialized Scientific-Practical Medical Center of Oncology and Radiology, Tashkent, the Republic of Uzbekistan

\title{
Analysis of main statistical indicators of oral and pharyngeal cancer in the Republic of Uzbekistan
}

Relevance: According to GLOBOCAN data for 2020, oral and pharyngeal cancer ranked 25th in mortality ( 98412 cases, $0.5 \%$ of all cancer deaths) and 26th in the number of diagnosed new cases (48 143 cases, $0.5 \%$ of all new cancer cases) in the world. Oral and pharyngeal cancer incidence is growing steadily globally and in the Republic of Uzbekistan. Oral and pharyngeal cancer ranks 16th in the structure of cancer incidence in the Republic of Uzbekistan, with a rate of 1.8 per 100000 people.

The purpose of the study was to analyze the main statistical indicators for tumors of the oral cavity and pharynx in the Republic of Uzbekistan in 2015-2021.

Methods: We analyzed the main statistical indicators for tumors of the oral cavity and pharynx in the Republic of Uzbekistan for 2015 2020 obtained from the Reporting Form \#7 "Information about malignant neoplasms cases."

Results: Over the past six years, the incidence rate per 100,000 people has increased from 1.4 in 2015 to 1.8 in 2020. In 2015-2020, in the Republic of Uzbekistan, 2,240 patients died from malignant neoplasms of the oral cavity and pharynx. The mortality rate per 100,000 people decreased from 1.4 in 2015 to 1.2 in 2020.

Conclusions: Tumors of the oral cavity and pharynx rank 16th in the structure of cancer incidence in the Republic of Uzbekistan and tend to grow. A recent increase in oral and pharyngeal cancer incidence and its late detection could be explained by worsening detection and diagnostics. The stabilization of oral and pharyngeal cancer mortality results in socio-economic losses for the Republic. The provided statistical data is the basis for improving the indicators of incidence and mortality related to oral and pharyngeal cancer in the Republic of Uzbekistan.

Keywords: epidemiology, malignant neoplasms (MNs) of the oral cavity and pharynx, statistics.

Introduction: Malignant neoplasms (MNs) of the head and neck represent a group of malignant neoplasms rather heterogeneous in histological nature and account for $18-20 \%$ of the total structure of oncological diseases [1]. MNs remain of primary importance in the clinical oncology of Uzbekistan, causing significant damage to the economy and social health [2-3]. MNs of the head and neck represent a heterogeneous group of tumors, with common tendencies towards the further spread and progression of the disease. Due to the variety of localizations of tumors and tissues from which tumors of the head and neck originate, the biology of tumor growth, metastasis pathways, tumor boundaries, signs, and symptoms of the disease are fundamentally different. Risk factors for the onset of the disease include smoking and alcohol abuse. About $60 \%$ of the oral cavity and pharyngeal cancer cases are detected at stages III-IV due to the latent period at the initial stages of the disease. The clinical picture is due to the tumor's initial localization and growth direction [4-7].

Recently, MNs have become one of the main problems in medicine. The number of newly reported cancer cases continues to rise worldwide, placing an enormous physical, emotional and financial burden on the population and the health care system. Unfortunately, the health system in low- and middle-income countries is not always prepared to handle this burden. According to Kachanov et al. an in-depth epidemiological analysis including anatomical localization and histological structure should be based on population registers' indicators, taking into account patient data from the registration of MN till the patient's death [8]. This data is collected worldwide in population cancer registries and allows to compare the morbidity and mortality rates [8]. In terms of territorial coverage, registers can be regional, national, global [7, 9].

The purpose of the study was to analyze the main statistical indicators for tumors of the oral cavity and pharynx in the Republic of Uzbekistan over the previous six years.

Materials and Methods: The research materials included statistical data on all cases of tumors of the oral cavity and pharynx in the Republic of Uzbekistan according to the reporting data for 2015-2020 provided by oncological institutions in the adopted state form of accounting and reporting documentation Ministry of Health of the Republic of Uzbekistan no. 7SSV "Information on malignant neoplasm cases." The received materials were processed using Microsoft Office 2016 (Excel, Word), OriginPro 8.6.0 (32-bit) Srl b97, Statistica 10.0, and other statistical programs.

Results: In 2020, 21976 newly reported cancer cases were registered in the Republic of Uzbekistan, including 9059 (41.22\%) in men and 12917 (58.77\%) in women. The increase in this indicator compared to 2019 accounted for $12.1 \%$. The incidence rate of cancer per 100000 populations in the Republic of Uzbekistan was 64.8, which is $12.1 \%$ lower than in 2019 and $15.6 \%$ higher than in 2009. By the end of 2020, the number of patients amounted to 107196 (in 2019 - 103,063), i.e., 0.3\% of the country's population. Of these, 61283 (57.2\%) were rural residents, 4505 (4.2\%) were children aged 0 to 17 years old.

Oral and pharyngeal cancer ranks $16^{\text {th }}$ in the structure of cancer incidence in the Republic of Uzbekistan, with a rate of 1.8 per 100000 people (Figure 1).

The number of patients with malignant tumors under observation for five or more years amounted to $37.8 \%$ of all cancer cases (vs. 38.1\% in 2019). The share of patients with tumors of the oral cavity and pharynx under observation for five or more years from the moment of diagnosis made up $37.8 \%$ in 2020 (vs. 45.7\% in 2015) of the total number of those registered with this diagnosis (Figure 2). This decrease in survival rates can speak of inadequate routine examination and preventive observation of patients after treatment. 


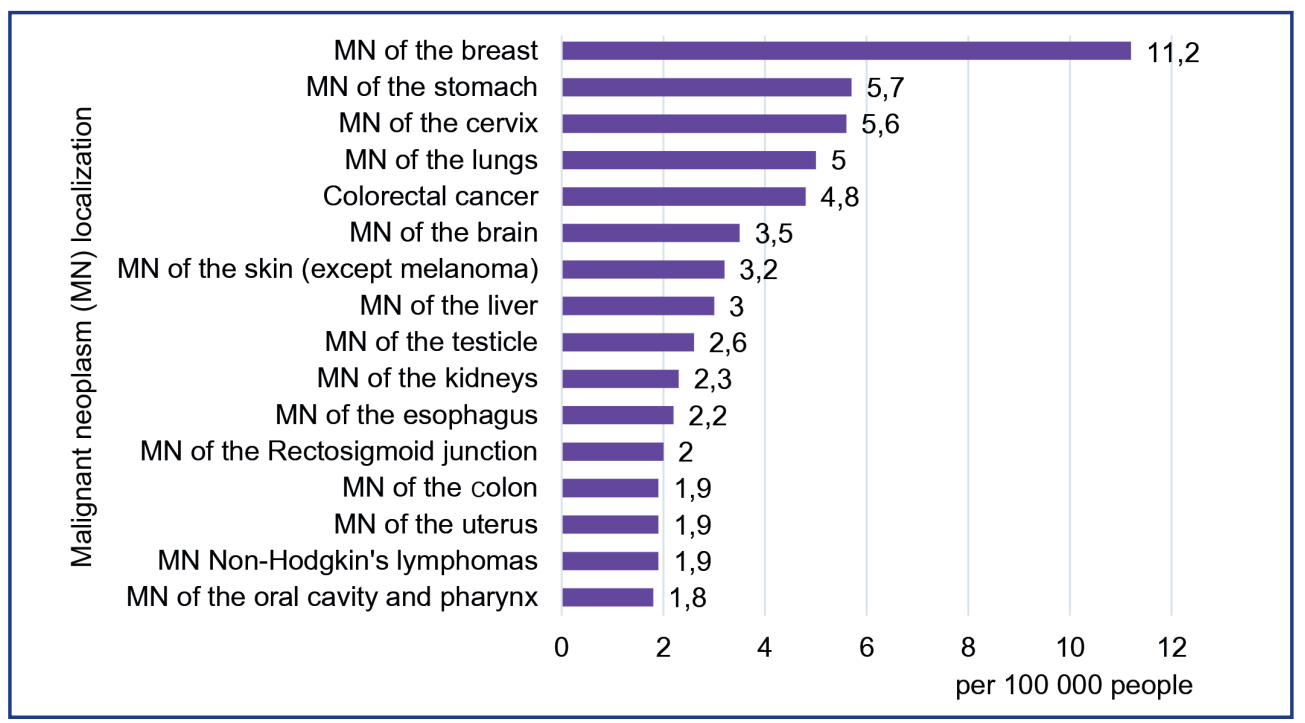

Figure 1 - Cancer incidence structure in the Republic of Uzbekistan, 2020

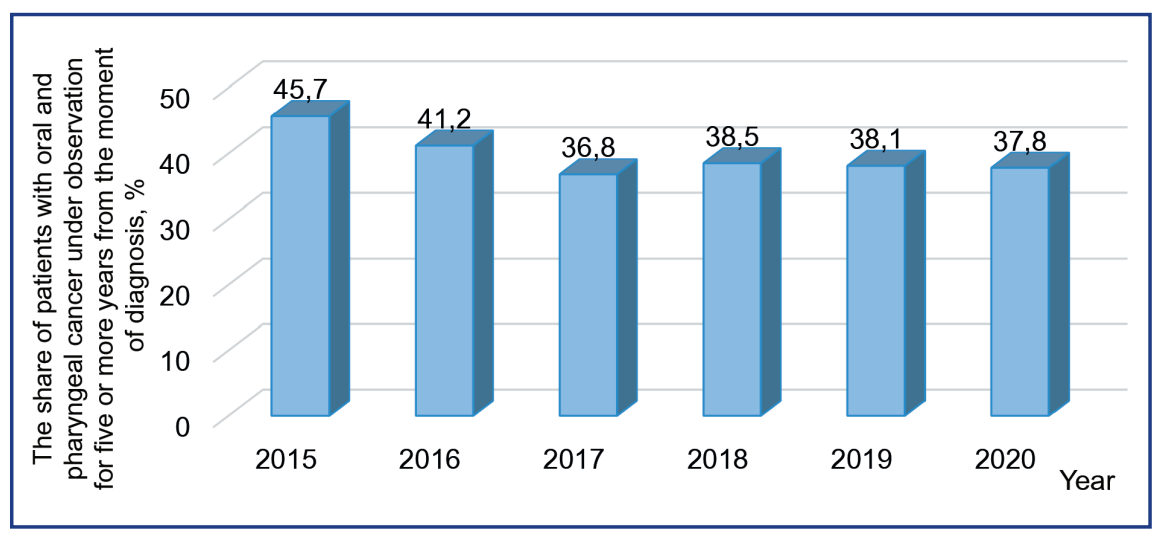

Figure 2 - Trends in 5-year survival of patients with oral and pharyngeal cancer in the Republic of Uzbekistan, 2015-2020

The oral and pharyngeal cancer incidence in the Republic of Uzbekistan has also increased in the study

period, from 1.4 per 100,000 people in 2015 to 1.8 in 2020 (Figure 3).

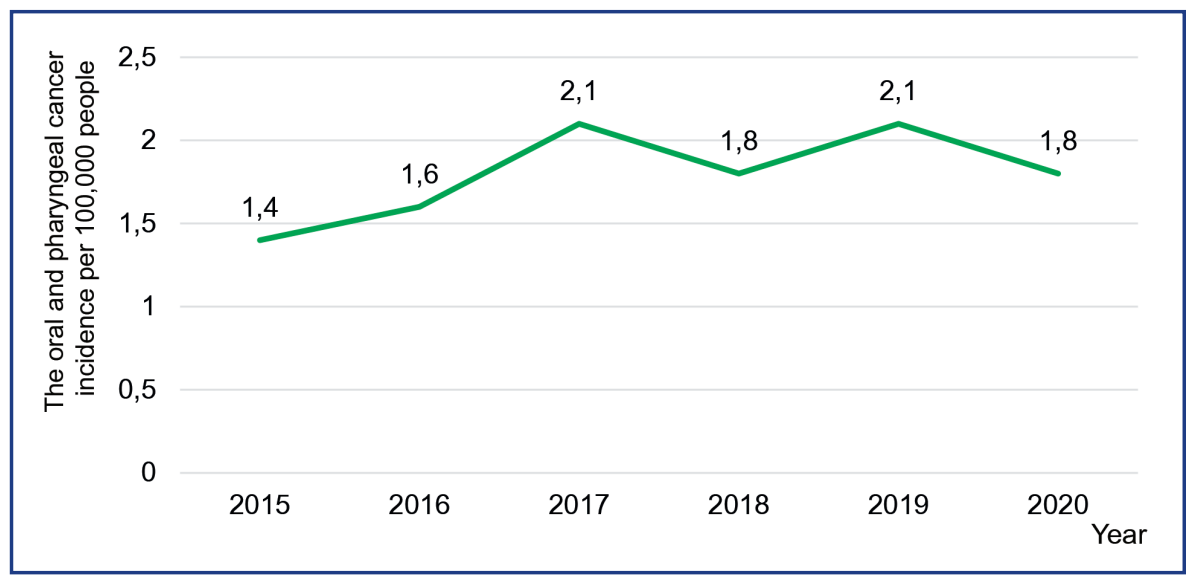

Figure 3 - Trends in oral and pharyngeal cancer incidence in the Republic of Uzbekistan, 2015-2020

The share of patients with morphologically identified oral and pharyngeal cancer has increased from $93.4 \%$ in 2019 to $93.9 \%$ in 2020 , although the highest percentage of $95.3 \%$ was registered in 2015 (Figure 4). This statistical analysis will help determine the causes for the observed fluctuations. 


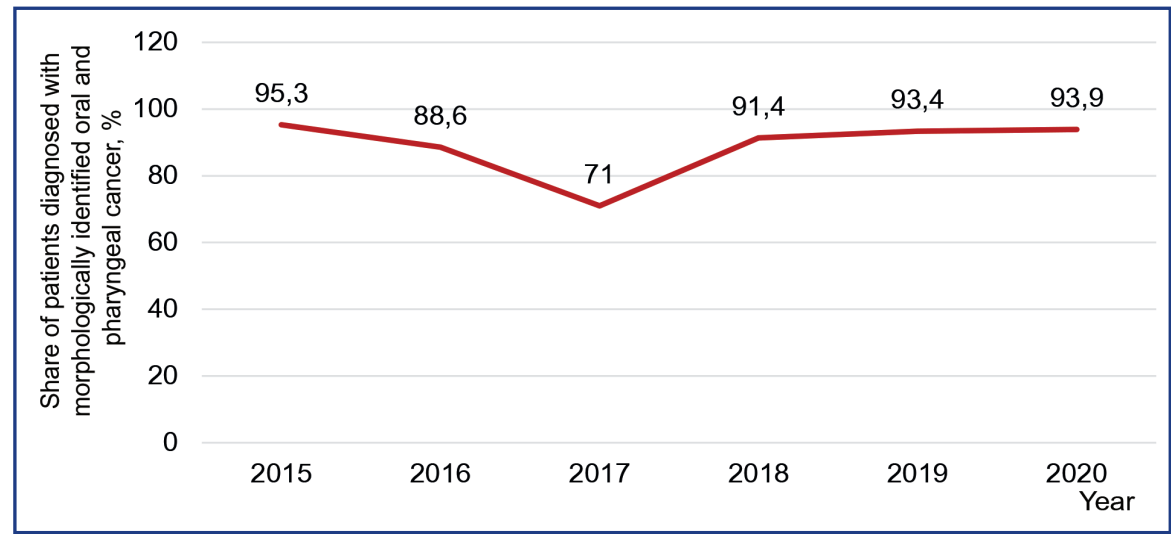

Figure 4 - Share of patients diagnosed with morphologically identified oral and pharyngeal cancer in the Republic of Uzbekistan, 2015-2020

The shares of oral and pharyngeal cancer cases diagnosed at early stages have stabilized. The share of stage III cases has decreased. The share1 of stage IV cases (the neglect rate) has grown at the expense of stage I-III cases
(Figure 5). The coronavirus outbreak led to the introduction of quarantine across the country, preventing patients from seeking timely medical care in the early stages of the disease.

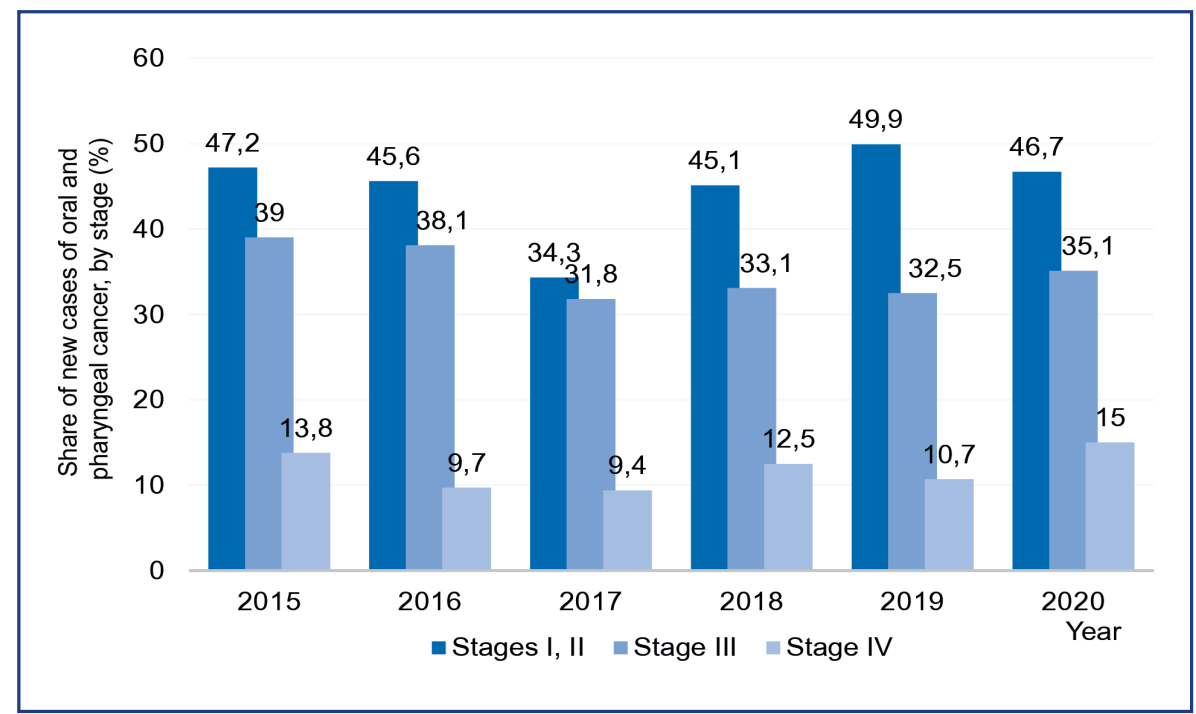

Figure 5 - The newly diagnosed cases in patients with oral and pharyngeal cancer in the Republic of Uzbekistan, by stage (\%), 2015-2020

Mortality of patients with oral and pharyngeal cancer in Uzbekistan in 2015-2020 decreased by $0.2 \%$, from 445 deaths (1.4\% of all patients with a verified diagnosis of oral and pharyngeal cancer) in 2015 to 393 (1.2\%) in 2020 (Figure 6). Con- sidering the neglect of the disease during the initial detection of a tumor, the issue of early diagnostics of head tumors remains relevant. Improving early diagnostics of head tumors could improve the patients' survival rate and quality of life.

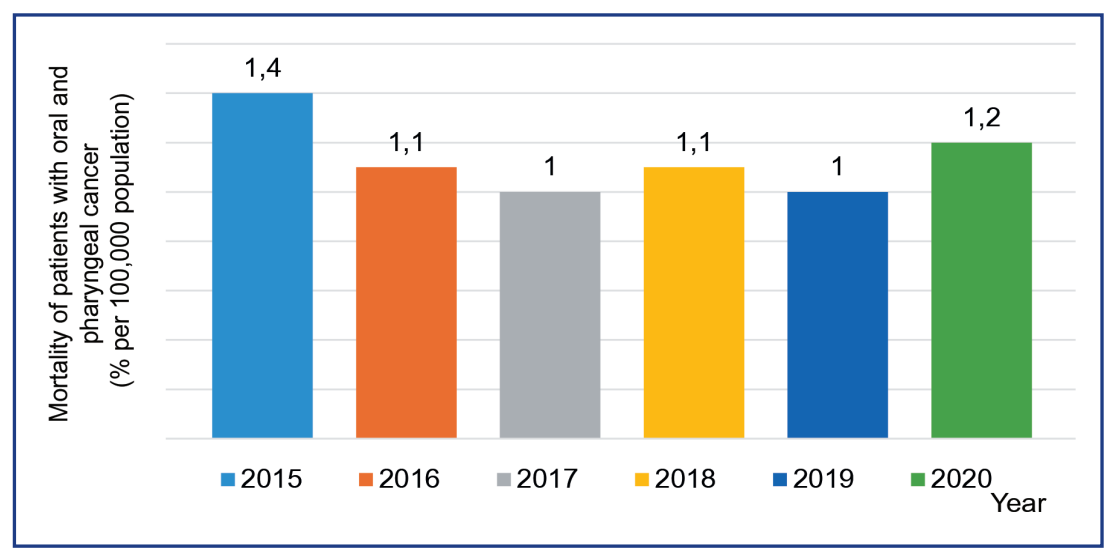

Figure 6 - Mortality of patients with oral and pharyngeal cancer in Uzbekistan, 2015-2020 (\% per 100,000 population) 
The treatment strategy for oral and pharyngeal cancer is changing. The new generation of chemotherapy techniques and combined treatment regimens has significantly improved the treatment outcomes with early and advanced stages of the disease. Most patients with oral and pharyngeal cancer (34.8\%) received combined treatment (Figure 7).

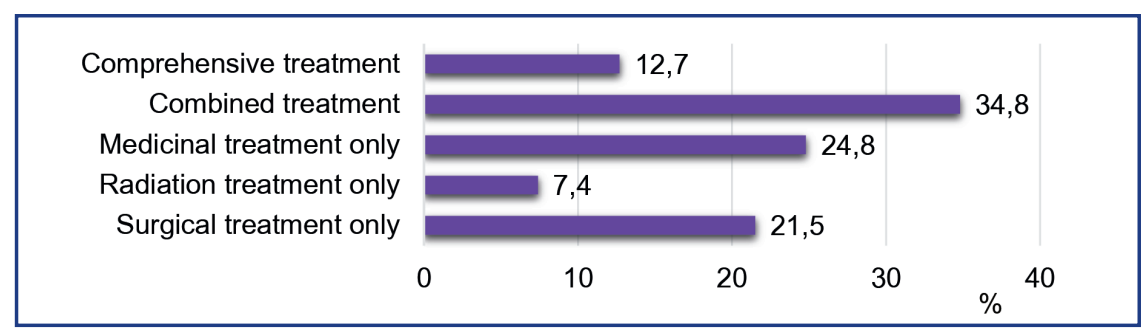

Figure 7 - The share of specialized treatment for oral and pharyngeal cancer in the Republic of Uzbekistan, 2020

Discussion: Most patients (about 60-70\%) with oral and pharyngeal cancer begin treatment already at the locally advanced stage of the disease. In 2020, almost every fifth patient in the Republic of Uzbekistan had an advanced cancer stage III-IV (Figure 4 and 5). For stage III-IV tumors, the principles of complex or combined treatment of localized tumors; for stage IVC cancer, due to the presence of distant metastases, only systemic therapy is feasible. Due to a significant local and/ or regional prevalence of the tumor, not resectable at diagnosis, stage III-IV oral and pharyngeal cancer is uncertain in terms of treatment tactics because the inability to perform surgery significantly reduces therapeutic possibilities (Figure 7).

Unfortunately, in the Republic of Uzbekistan, these patients receive mainly palliative chemotherapy or symptomatic treatment. In other countries, they apply simultaneous chemoradiotherapy to treat not resectable tumors of the oral cavity and pharynx, with very satisfactory treatment results.

Conclusion: The analysis showed that tumors of the oral cavity and pharynx rank 16th in the structure of cancer incidence in the Republic of Uzbekistan and tend to grow. A recent increase in oral and pharyngeal cancer incidence and its late detection could be explained by worsening detection and diagnostics. The stabilization of mortality from oral and pharyngeal cancer result in socio-economic losses for the Republic. The provided statistical data is the basis for improving the indicators of incidence and mortality related to oral and pharyngeal cancer in the Republic of Uzbekistan.

\section{References:}

1. Грибова О.В. Нейтронная терапия злокачественных новообразований головы и шеи: дисс. ... док.мед.наук: 14.01.12, 14.01.13. - Томск, 2019. - C. 5. [Gribova O.V. Nejtronnaya terapiya zlokachestvennyx novoobrazovanij golovy i shei: diss. ... dok.med.nauk: 14.01.12, 14.01.13. - Tomsk, 2019. - S. 5 (in Russian)]. https://www.dissercat.com/content/neitronnaya-terapiya-zlokachestvennykh-novoobrazovanii-golovy-i-shei;

2. Раджабова 3.А., Ткаченко Е.В., Морозов И.А., Ракитина Д.А., Нажмудинов Р.А. Успешное лечение распространен- ного рака носоглотки с метастатическим поражением костного мозга (клиническое наблюдение) // Опухоли головы и шеи. - 2015. - № 3. - C. 55-57. [Radzhabova Z.A., Tkachenko E.V., Morozov I.A., Rakitina D.A., Nazhmudinov R.A. Uspeshnoe lechenie rasprostranennogo raka nosoglotki s metastaticheskim porazheniem kostnogo mozga (klinicheskoe nablyudenie) // Opuxoli golovy i shei. - 2015. - № 3. - S. 55-57 (in Russian)]. https://doi.org/10.17650/2222-1468-2015-5-3-55-58;

3. Чебнер Б.Э., Линч Т.Дж., Лонго Д.Л. Руководство по онкологии / под ред. В.А. Хайленко. - М.: МЕДпресс-информ, 2011. - C. 629-644. [Chebner B.E., Lynch T.J., Longo D.L. Rukovodstvo po onkologii / pod red. V.A. Xajlenko. - M.: MEDpress-inform, 2011. - S. 629-644 (in Russian)]. http://www. bookvamed.com.ua/images/Pages/o01125.pdf;

4. Кандакова Е.Ю. Клинико-экспериментальное обоснование повышения эффективности сочетанной фотонно-нейтронной терапии опухолей головы и шеи: дисс. ... док.мед.наук: 14.01.13, 14.01.12. - М.: ФГБУ « Российский научный чентр рентгенорадиологии» Минздрава России, 2015. - C. 6. [Kandakova E.Yu. Kliniko-e'ksperimental'noe obosnovanie povysheniya e'ffektivnosti sochetannoj fotonno-nejtronnoj terapii opuxolej golovy i shei: diss. ... dok.med.nauk: 14.01.13, 14.01.12. - M.: FGBU « Rossijskij nauchnyj centr rentgenoradiologii» Minzdrava Rossii, 2015. - S. 6 (in Russian)]. https:// www.rncrr.ru/upload/Doc/kondakova_eu-autoreferat.pdf;

5. Tillyashaykhov M.N., Djanklich S.M., Ibragimov S.N., Imamov O.A. Analysis of cancer incidence structure in the Republic of Uzbekistan // Oncology and Radiology of Kazakhstan. - 2021. - Vol. 61(3). - P. 4-8 https://doi.org/10.52532/25216414-2021-3-61-4-8;

6. Bray F., Ferlay J., Soerjomataram I., Siegel R.L., Torre L.A., Jemal A. Global cancer statistics 2018: GLOBOCAN estimates of incidence and mortality worldwide for 36 cancers in 185 countries // CA Cancer J. Clin. -2018. - Vol. 68 (6). - P. 394-424. https://doi.org/10.3322/caac.21492;

7. Hyuna S., Jacques F., Rebecca L., Mathieu L., Isabelle S. Ahmedin J., Freddie B. Global Cancer Statistics 2020: GLOBOCAN Estimates of Incidence and Mortality Worldwide for 36 Cancers in 185 Countries // CA Cancer J. Clin. - 2021. - Vol. 71. - P. 209249. https://doi.org/10.3322/caac.21660;

8. Качанов Д.Ю., Абдуллаев Р.Т, Добреньков К.В., Варфоломеева С.Р. Методология работы детского популяционного канцер-регистра // Онкогематология. - 2009. - № 4. - C. 51-60. [Kachanov D.Yu., Abdullaev R.T, Dobren'kov K.V., Varfolomeeva S.R. Metodologiya raboty detskogo populyacionnogo kancer-registra // Onkogematologiya. - 2009. № 4. - S. 51-60 (in Russian)]. https://cyberleninka.ru/article/n/ 
metodologiya-raboty-detskogo-populyatsionnogo-kantserregistra;

9. GBD 2015 Risk Factors Collaborators. Global, regional, and national comparative risk assessment of 79 behavioral, environmental and occupational, and metabolic risks or clusters of risks, 1990-2015: a systematic analysis for the Global Burden of Disease Study 2015 // Lancet. - 2016. - Vol. 388 (10053). P. 1659-1724. https://doi.org/10.1016/S0140-6736(16)31679-8.

\section{ТҰЖЫРЫМ}

\section{Ж.М. Алимов ${ }^{1}$, Н.С. Каримова ${ }^{1}$}

1Республикалық мамандандырылған онкология және радиология ғылыми-практикалық медициналық орталығы, Ташкент, Өзбекстан Республикасы

\section{Өзбекстан Республикасындағы ауыз қуысы мен жұтқыншақ обырының негізгі статистикалық көрсеткіштерін талдау}

Өзектілігі: 2020 жылғы GLOBOCAN - нің әлемдік мәліметтеріне сәйкес, ауыз қуысы мен жұтқыншақ қатерлі ісігі бойынша болатын өлімжітім 25-ші орынды алса (98,412 жағдай, қатерлі ісік ауруынан болатын барлық өлімнің 0,5\%) диагноз қойылған жаңа жағдайлардың саны бойынша 26-шы орында (48,143 жағдай, қатерлі ісік ауруының 0,5\%). Ауыз қуысы мен жұтқыншақтын қатерлі ісігі бүкіл әлемде және Өзбекстан Республикасында тұрақты өсуде. Ауыз қуысы мен жұтқыншақтың қатерлі ісігі Өзбекстан Республикасында қатерлі ісік ауруының құрылымында 16-шы орында тұрса, 100000 адамға 1,8 көрсеткіш.

Зерттеудің мақсаты Өзбекстан Республикасындағы ауыз қуысы мен жұтқыншақ ісіктерінің 2015-2021 жылдардағы негізгі статистикалық көрсеткіштерін талдау болды.

Әдістері: Өзбекстан Республикасында 2015-2020 жылдардағы ауыз қуысы мен жұтқыншақ ісіктерінің негізгі статистикалық көрсеткіштері «Қатерлі ісік жағдайлары туралы мәліметтер» № 7 есеп беру формасынан алынды.

Нәтижелері: соңғы алты жылда 100000 адамға шаққанда сырқаттанушылық көрсеткіші 2015 жылғы 1,4-тен 2020 жылы 1,8-ге дейін ұлғайды. 2015-2020 жылдары Өзбекстан Республикасында ауыз куысы мен жұтқыншақтың қатерлі ісіктерінен 2240 науқас қайтыс болды. 100000 адамға шаққандағы өлім 2015 жылғы 1,4-тен 2020 жылы 1,2-ге дейін төмендеді.

Қорытынды: Өзбекстан Республикасында қатерлі ісік ауруының құрылымында ауыз қуысы мен жұтқыншақтың ісіктері 16-шы орында және өсу үрдісіне ие. Жақында ауыз қуысы мен фарингальды қатерлі ісік ауруының өсуі және оны кеш анықтау диагноздың нашарлауымен түсіндіріледі. Ауыз қуысы мен жұтқыншақ қатерлі ісігінен болатын өлім-жітімді тұрақтандыру Республика үшін әлеуметтік-экономикалық шығындарға алып келеді. Ұсынылған статистикалық деректер Өзбекстан Республикасында ауыз қуысы мен жұтқыншақ қатерлі ісігінің аурушаңдығы мен өлім-жітім көрсеткіштерін жақсарту үшін негіз болып табылады.

Түйінді сөздер: эпидемиология, ауыз қуысы мен жұтқыншақтың қатерлі ісіктері (ҚІ), статистика.

\section{АННОТАЦИЯ}

\author{
Ж.М. Алимов ${ }^{1}$, Н.С. Каримова ${ }^{1}$
}

1Республиканский специализированный научно-практический медицинский центр онкологии и радиологии, Ташкент, Республика Узбекистан

\section{Анализ основных статистических показателей рака полости рта и глотки в Республике Узбекистан}

Актуальность: Согласно мировым данным GLOBOCAN за 2020 год, рак полости рта и глотки занял 25-е место по смертности (98 412 случаев, 0,5\% всех смертей от рака) и 26-е место по количеству диагностированных новых случаев (48 143 случая, 0,5\% всех новых случаев рака). Заболеваемость раком полости рта и глотки неуклонно растет во всем мире и в Республике Узбекистан. Рак полости рта и глотки занимает 16 место в структуре заболеваемости раком в Республике Узбекистан с показателем 1,8 на 100000 человек.

Целью исследования явился анализ основных статистических показателей опухолей полости рта и глотки в Республике Узбекистан за 2015-2021 годы.

Методы: Были проанализированы основные статистические показатели опухолей полости рта и глотки в Республике Узбекистан за 2015-2020 годы, полученные из Отчетной формы № 7 «Сведения о случаях злокачественных новообразований».

Результаты: За последние шесть лет показатель заболеваемости на 100000 человек увеличился с 1,4 в 2015 году до 1,8 в 2020 году. В 2015 2020 годах в Республике Узбекистан от злокачественных новообразований полости рта и глотки умерли 2240 пациентов. Смертность на 100000 человек снизилась с 1,4 в 2015 году до 1,2 в 2020 году.

Заключение: Опухоли полости рта и глотки занимают 16 место в структуре заболеваемости раком в Республике Узбекистан и имеют тенденцию к росту. Недавний рост заболеваемости раком полости рта и глотки и его позднее обнаружение можно объяснить ухудшением выявления и диагностики. Стабилизация смертности от рака полости рта и глотки приводит к сочиально-экономическим потерям для Республики. Представленные статистические данные являются основой для улучшения показателей заболеваемости и смертности от рака полости рта и глотки в Республике узбекистан.

Ключевые слова: эпидемиология, злокачественные новообразования (ЗН) полости рта и глотки, статистика.

Transparency of Research - Authors are responsible for the content of this article.

Conflict of interest: The authors declare that they have no conflicts of interest.

Authors' contribution: research design, the pursuance of the research - Alimov J.M.; literature study, data analysis, writing the manuscript - Karimova N.S. Information about the authors:

Alimov J.M. - Head of Radiotherapy Department, Uzbekistan, 100174, Tashkent city, Farobiy 383, e-mail: alimovjamshid@gmail.com,

ID ORCID: https://orcid.org/0000-0002-7644-2206;

Karimova N.S. (correspondent author) - Radiation oncologist, PhD, Uzbekistan, 100174, Tashkent city, Farobiy 383 ,

tel.: +998908059315, e-mail: nkskns19@gmail.com, ID ORCID: https://orcid.org/0000-0001-6277-0447.

Acknowledgements: We express our gratitude to prof. M.N. Tillyashaikhov for scientific advice and corrections in the process of writing the manuscript and to the chief physician of the RSSPMCOandR O.M. Akhmedov for administrative support of the study. 